Article

\title{
Analysis of the Use and Perception of Shared Mobility: A Case Study in Western Australia
}

\author{
Craig Standing ${ }^{1}$, Ferry Jie ${ }^{1}\left(\mathbb{D}\right.$, Thi Le $^{2, *} \mathbb{D}$, Susan Standing ${ }^{1}$ and Sharon Biermann ${ }^{3} \mathbb{D}$ \\ 1 School of Business and Law, Edith Cowan University, Joondalup, WA 6027, Australia; \\ craigstanding@bigpond.com (C.S.); f.jie@ecu.edu.au (F.J.); s.standing@ecu.edu.au (S.S.) \\ 2 Murdoch Business School, Murdoch University, 90 South Street, Murdoch, WA 6150, Australia \\ 3 PATREC, University of Western Australia, Crawley, WA 6009, Australia; sharon.biermann@uwa.edu.au \\ * Correspondence: thi.le@murdoch.edu.au
}

check for

updates

Citation: Standing, C.; Jie, F.; Le, T.; Standing, S.; Biermann, S. Analysis of the Use and Perception of Shared Mobility: A Case Study in Western Australia. Sustainability 2021, 13, 8766. https://doi.org/10.3390/su13168766

Academic Editor: Jungho Baek

Received: 8 June 2021

Accepted: 3 August 2021

Published: 5 August 2021

Publisher's Note: MDPI stays neutral with regard to jurisdictional claims in published maps and institutional affiliations.

Copyright: (c) 2021 by the authors. Licensee MDPI, Basel, Switzerland. This article is an open access article distributed under the terms and conditions of the Creative Commons Attribution (CC BY) license (https:/ / creativecommons.org/licenses/by/ $4.0 /)$.

\begin{abstract}
The sharing economy has acquired a lot of media attention in recent years, and it has had a significant impact on the transport sector. This paper investigates the existing impact and potential of various forms of shared mobility, concentrating on the case study of Wanneroo, Western Australia. We adopted bibliometric analysis and visualization tools based on nearly 700 papers collected from the Scopus database to identify research clusters on shared mobility. Based on the clusters identified, we undertook a further content analysis to clarify the factors affecting the potential of different shared mobility modes. A specially designed questionnaire was applied for Wanneroo's residents to explore their use of shared mobility, their future behaviour intentions, and their perspectives on the advantages and challenges of adoption. The empirical findings indicate that the majority of respondents who had used shared mobility options in the last 12 months belong to the low-mean-age group. The younger age group of participants also showed positive views on shared mobility and would consider using it in the future. Household size in terms of number of children did not make any impact on shared mobility options. Preference for shared mobility services is not related to income level. Bike sharing was less commonly used than the other forms of shared mobility.
\end{abstract}

Keywords: shared mobility; shared mobility; facilitator; barriers; ride sharing; car sharing; carpooling; bike sharing

\section{Introduction}

The development of technology has accelerated a growing transition from conventional travel modes to shared mobility [1]. Shaheen et al. [2] defined shared mobility as different modes of transportation that are shared on an as-needed basis. Shared mobility comprises various new forms such as car sharing, carpooling, ride sharing or bike sharing, which are growing rapidly in recent years $[3,4]$. This transition requires a comprehensive understanding by policy makers, transportation planners and managers about the effects of shared mobility on public transport demand and road use, as well as regulation to control and adjust these increasing collaborative consumptions [5]. The majority of existing studies indicated that shared mobility would reshape urban transportation [6]. The most common advantages of shared mobility include reducing congestion, pollution, and transportation costs, creating sustainable travel behaviour and sustainable urban infrastructure $[7,8]$. However, shared mobility is not a simple shortcut to create sustainable transportation based on modern technology solutions [9]. For instance, although shared mobility services such as bike sharing or carpooling have opened the prospect of urban mobility emission reduction [10], motorbike ride sharing in Indonesia was found to be ineffective in mitigating air pollution or carbon dioxide emissions [11]. Several critics even predicted that shared mobility options were likely to collapse soon as these services would make the traffic worse and create minor impacts on environment protection [12]. As there is a lack of consensus on how shared mobility will affect people's travel behaviour and the urban 
landscape, the broad deployment of shared mobility needs an intensive investigation of solutions to conquer challenges, such as designing a proper ride mechanism and building trust among unknown users on the online systems. Technology-enabled forms of collaborative consumption are in their infancy, but it is apparent that they have already had a disrupting effect on government policies and transportation regulations. The arrival of Uber, for example, has resulted in disruption in the taxi industry [13] and policy changes in Australia. Governments are investing extensively in transportation infrastructure, which features the long-term urban form. The possible influence of future demand development must be investigated and monitored cautiously. Collaborative consumption and sharing economies have increased travel options and can significantly affect private vehicle use, although the extent of the effect is still unclear [14].

Therefore, this paper aims to explore the use and perception of shared mobility through bibliometric analysis of 700 papers collected from the Scopus database to identify research clusters on the recent research topic. From the identified research cluster, we used a case study in Wanneroo, Western Australia, to identify in-depth trends in shared mobility adoption and the possible implications of these services on future transportation demand from the user's perspective, which is often neglected in existing research [15].

This paper is structured as follows. The following section begins with the definitions of critical terms in shared mobility, then the research methodology and findings from the bibliometric and in-depth analysis are outlined. The case study of Wanneroo is carried out in Section 4. Finally, Section 5 outlines the conclusion and recommendations for policy makers.

\section{Definition of Shared Mobility}

The sharing economy in transportation for this report is categorised into car sharing, carpooling, ride sharing, and bike sharing.

Car sharing programs allow members to rent and operate a car for a specified period before returning it to a set location. Car sharing includes corporate schemes or car clubs such as Zipcar, owned by Avis, one of the most extensive car sharing services globally; and Hertz 24/7, which operates a car sharing scheme in Australia. Members of these schemes are often well educated, professional, and live in urban areas; they rely on car sharing programs for long and small trips. Car-sharing schemes can be further divided into manufacturers' car-sharing schemes, such as BMW's DriveNow and ReachNow as well as Daimler's Car2Go, and peer-to-peer schemes such as Car Next Door.

Carpooling enables one individual to share the journey and split the associated cost with the other passengers. Dense urban regions are reported to have many car sharing and carpooling use. However, there still exists a difference in demographics among carpooling and car sharing users. Carpool members are mostly blue-collar employees, tend to drive because there is no other transport available and have more financial restrictions than car-share members [16]. In contrast, existing literature on carpooling suggest that a greater number of women use carpooling services. Studies suggest the key driver of carpooling is employer size, followed by a desire to reduce congestion, while other motivations showed negligible impacts [17]. Despite the success of carpooling for short trips, BlaBlaCar has gained popularity for long-distance journeys.

Ride sharing is a peer-to-peer service in which the car owner accepts ride requests from other service members in exchange for a charge. Through apps such as UberX, on-demand ride sharing allows the driver to respond instantly to requests for rides and allows members to track their request. Payment is also made through the proprietary app. Dynamic ride sharing also involves booking a ride on short notice, but the journey is likely to be shared with other people, often strangers, taking the same or a similar route. Passengers can be picked up and dropped off anywhere along the route. This requires some flexibility in timing and route planning but can reduce the cost of a journey and the number of vehicles needed to cover the route. UberPool is an example of a dynamic ride sharing service. The most popular findings from prior research indicated that ride sharing services 
users were mainly in the younger adult, highly educated and high-income groups $[18,19]$. However, an opposite trend was confirmed in the contemporary study, where users of ride sharing primarily came from low- and middle-income households [20-22].

The bike sharing program was first introduced in 1996 in the United Kingdom, then mainly adopted in Barcelona and Paris in 2007, and has recently spread to more than one thousand cities worldwide [23]. The significant growth in bike sharing is motivated by increasing healthy vision, sustainable development and carbon dioxide reduction [24]. UberBike is currently available at several train stations and metro areas in Perth, Western Australia. The introduction of electric bikes for longer rides and to make riding more comfortable could result in increased use of this type of service. Thus, understanding the contribution of bike sharing to the context of urban mobility may influence strategic work for shared mobility networks. See Figure 1.

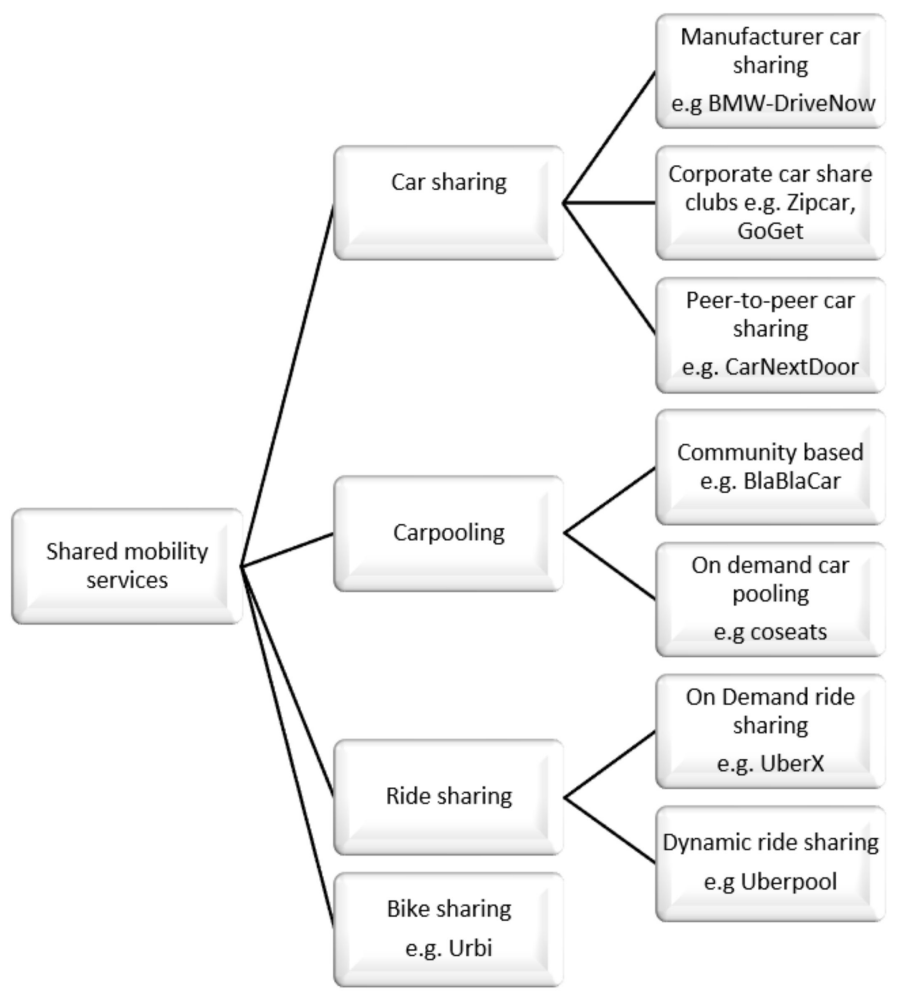

Figure 1. Types of shared mobility schemes.

\section{Research Methodology}

Bibliometric analysis was combined with further content analysis. The VOS viewer was used to extract information from papers forming data clusters based on a similar research theme [25]. Content analysis enables identifying insights, themes, research diversification, and research trends from papers classified in the clusters as well as in-depth analysis according to research focus.

This study applied three steps to achieve the research aims, which are described as follows:

Step 1: Analysis scope delimitation and article selection. We searched online published articles, including articles in the press and pre-publication of articles to enrich the final list of articles, until the cut-off date, 15 February 2021, from the Scopus database. Boolean operator "OR" was employed due to the various definitions used in this research area, and the articles were chosen if the following terms appeared in the title, abstract, or keyword fields: shared mobility, transport sharing, ride sourcing, ride sharing, carpooling, bike sharing, and car sharing. This search led to 692 results that form the corpus of the present study. 
Step 2: Descriptive analysis of papers: using the VOS viewer to identify the research clusters. Network nodes can be divided into clusters or modules where the relation (edge density) between the same nodes is greater than that of different clusters [26,27]. In the past, data clustering has been used to classify a series of papers, also called modularity [27]. Data clustering has been increasingly focused on by researchers and organizations, making it a key area of research in data visualization [28].

Step 3: In-depth analysis of papers, interpretation and discussion of findings: the indepth analysis of papers in each data cluster is conducted, mainly focusing on the current research topic to identify the key drivers, facilitators and barriers of shared mobility.

\subsection{Data Clustering}

The VOS viewer is used for forming data clusters based on a similar research theme. Papers associated with a cluster have strong relations with other articles within the cluster while having limited linkage with the publications of different clusters [29]. As the papers within one cluster are categorised based on similarity, clustering is considered an effective tool in exploring different dimensions of research topics existing in recent literature. A total of eight clusters were found, and only related items were mapped. Different colours represent different clusters, and the circle represents the higher weight of an item. More details are presented in Figure 2.

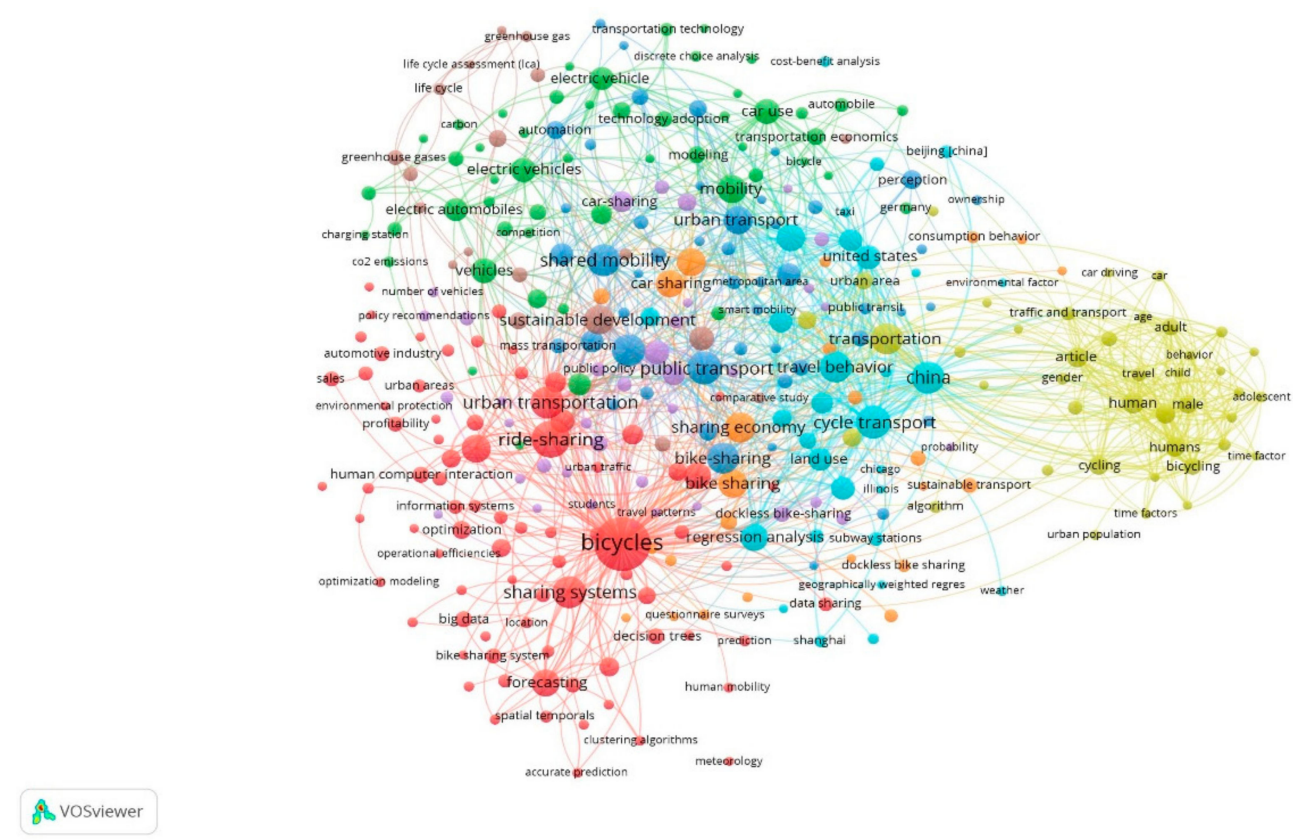

Figure 2. Research clusters generated by the VOS viewer.

Cluster 1 articles focus on influential drivers of different modes of shared mobility and their effects. In this cluster, papers concentrated on various subthemes of shared mobility options such as accident prevention, environmental factors, influential factors, smart city, traffic control, traffic congestion, travel behaviour, public transport and transportation systems. Cluster 2 articles focus on future prospects, public attitudes, sustainable mobility, market conditions, care use, carbon dioxide, and transportation infrastructure. Cluster 3 articles focus on assessment method, commuting, conceptual framework, modal shift, perception, shared mobility, ride hailing, ride sourcing, bike sharing, policy making, and behavioural research. Cluster 4 articles focus on using shared mobility in different countries, consumer attitudes, consumer behaviour, and urban population. Cluster 5 articles focus on topics associated with demand analysis, mobile application, factor analysis, travel distance, travel mode choices, service providers, and travel patterns. Cluster 6 articles focus on accessibility, land use, subway stations, and traffic management. Cluster 7 articles 
focus on collaboration consumption, perceived ease of use, sharing economy, economic and social effects. Cluster 8 articles focus on air quality, climate change, emission control, environmental impacts, greenhouse gas, and life cycle. To conclude, papers in Cluster 1 dominate the research topics on shared mobility. They evolve the research of various factors affecting shared mobility such as environmental factors, accident prevention and how shared mobility services reshape urban transportation, use of shared mobility and travel behaviour. The in-depth analysis of these papers is necessary to provide guidelines to survey residents in Wanneroo to find out the implication of shared mobility services on future transportation demand from the user's perspective.

\subsection{In-Depth Analysis-Drivers of Shared Mobility}

In existing literature, economics is found to be one of the main drivers of shared mobility. For instance, ride sharing is proven to save travelling cost, competing effectively with the conventional taxi industry and having led to a lower service price by approximately $20 \%$ [30]. The convenience and availability of more choice in ride sharing and the feeling of fun are vital factors to beat the conventional taxi model [31]. A report by Deloitte [32] revealed that the waiting time for a taxi was three minutes, as the majority of Uber users picked up in approximately four and a half minutes while this number for the taxi industry was eight minutes. The study also indicated the lower risk related to ride sharing services due to the transparency of both passenger and driver profile before pick-up. Such services can be considered a solution to traffic congestion and road infrastructure expenses by the government [33].

Carpooling is motivated by cost savings and various drivers consisting of environmental impact because fewer cars operate on the road. Further, carpooling is found to develop societal structures as travellers work together to select the optimal journey instead of being individualistic [34]. Gender is the most important predictor of carpooling use [35,36].

Technological innovation has dramatically changed conventional carpooling by connecting riders with drivers in real time. Although ride sharing services have proliferated, it is not apparent how these services affect the behaviour of commuters [37]. If enough people use carpooling services in a locality, this can make an essential difference to vehicle miles travelled. A study on the capability of dynamic carpooling [38] has shown that twenty per cent of travellers to the UC Berkeley campus are more likely to replace their private car with carpooling services.

Psychological barriers, such as attitudes and perceptions, affect carpooling more than socio-demographic barriers [39]. Social-economic characteristics, such as education, age, income, family structure, and non-motorized mode use, are the strongest indicators when forecasting car sharing and ride sharing users [40-42]. A study in Greece profiling car sharing users found that low- to medium-income passengers, who were environmentally conscious and utilize taxis for social purposes, had a high probability of becoming car sharing members [41].

Bike sharing is significantly affected by measures of effort and comfort [43], and distance to docking station is the key predictor of bike sharing use [44]. The number of bike sharing trips increases when more bike lanes or bike paths are close to the bike sharing station $[45,46]$. Land use and built environments such as train and bus stations, restaurants and universities are also considered motivations for bike sharing use $[47,48]$. The bike sharing service is more often used on weekdays than weekends, as well as during peak hours, and people tend to use this service if the travel time is less than $30 \mathrm{~min}$ [49].

\subsection{In-Depth Analysis - Facilitators of the Sharing Economy in Transportation}

Facilitators refers to elements that contribute to but are not responsible for a change. Numerous facilitators are interconnected involved in situations that lead to behavioural changes brought about by technological advancements and the internet (Table 1). Collaboration, online sharing, and social commerce, in particular, have created favourable conditions for the sharing economy as people become more knowledgeable [50]. 
Table 1. Facilitators and barriers for shared mobility.

\begin{tabular}{|c|c|}
\hline Facilitators of Shared Mobility & Barriers to Shared Mobility \\
\hline Trust & Over-regulation \\
\hline Adequate regulation & Experiences not consistent \\
\hline Technology platforms, easy to use & $\begin{array}{c}\text { Lack of trust until recommended by someone } \\
\text { they trust }\end{array}$ \\
\hline Rethinking value of ownership & $\begin{array}{l}\text { Set-up costs and lack of profit (risk) } \\
\text { Long held norms and values (independence, private } \\
\text { space, status) }\end{array}$ \\
\hline
\end{tabular}

Web 2.0 (Web 2.0 refers to the current state of the web, where there are more usergenerated content and usability for end-users) has increased the amount of user-generated content and altered the way information is created and consumed [51]. Collaboration between users online is conducted through peer-to-peer platforms [52]. A range of factors affect participation in these systems, including reputation, enjoyment, and extrinsic motivation $[52,53]$. Social media enables interactions in social commerce, in which user contributions are incorporated into the purchasing and selling process. Online recommendations from friends and, to a lesser extent, others can be highly compelling when it comes to persuading someone to purchase a product [50]. It is through the vast number of social network members that social commerce achieves influence. The users' attitude and behaviour are critically affected by word of mouth [54]. Trust is a crucial feature of shared mobility. The majority of consumers will only trust a service or regard it as good if it has been suggested by someone they trust [50]. Ride sharing, for instance, relies on passengers' trust in the driver to complete the route safely, making driver recommendations extremely valuable when choosing this method of transport.

The rapid growth in shared mobility is supported by the prevalence of mobile internet technology and cutting-edge technologies such as the Global Positioning System (GPS) and cloud computing techniques. The speed in communication provided by mobile devices is crucial in a variety of transportation-related circumstances. Due to the rise of the smartphone industry, a competitive market has evolved for smartphone applications that fulfils a specific purpose, such as organizing a ride [55]. However, smartphones have weaknesses such as limited battery capacity, slow data transfer speeds, postponed input function, and narrow screens [56].

Not many people can afford the expensive costs required to remain the owner of a private car affected by unstable fuel prices, increasing maintenance costs, and the insurance and purchase cost of the car. This makes car sharing attractive to more and more people. Users can enjoy a variety of cars depending on their current requests without the burden of a car purchase [41]. Moreover, consumption habits have changed in the last decade [57]. Consumers seem to prefer to pay for the experience of short-time access to property than buying and owning them [58]. Ownership is no longer the final expression of consumer desire [59].

The transport sector is regulated heavily in most countries to ensure sustainability for public interests, but this may damage innovation. Many researchers have debated the right level of regulation to serve public values and the private sector. The development of shared mobility requires the support and implementation of facilitative legislation [60]. Transport regulation lags behind innovation in the industry and does not adequately accommodate new phenomena such as ride sharing or car sharing, and this may become an obstacle for shared mobility growth. For example, in Sweden, the lack of a formal definition of car sharing caused difficulties for local governments when designating parking for car sharing vehicles [60].

\subsection{In-Depth Analysis-Barriers to Shared Mobility}

Shared mobility involves a level of service risk (Table 1). While guidelines can be used to formulate decisions, the overall service experience is likely to be inconsistent. Generally, 
trust is absent until someone makes a suggestion. Several countries initially opposed ride sharing, for instance, Australia, although this has recently shifted in most states [61]. Nonetheless, an overabundance of ride sharing restrictions could make it complicated and costly for drivers to start this type of business [62]. Some argue for the development of more comprehensive laws that do not inhibit innovation. Before, regulators treated the sharing economy exclusively through the lens of established procedures. Since many sharing economy practices blur the line between personal and business activity, a new legal framework is required. A minimal set of legal standards is required to take the distinctive characteristics of innovative sharing economy practices into account and allow for future development [63]. However, it is stated that the aims of local governments and sharing economy enterprises are frequently aligned and that ride sharing enterprises must take the initiative in advocating for themselves [62]. Additionally, there has been significant debate over whether Uber drivers can earn a decent profit given the associated cost [50].

Despite the sharp growth in ride sharing, some argue that its influence on the transport landscape is primarily small. It is typically limited to metropolitan areas and more welleducated, young adults [64]. Additionally, it is frequently used to replace single-occupant driving excursions. One survey on millennials across California discovered that they would have walked or cycled if they had not used ride sharing, even though previous generations said they would have driven [65]. How ride sharing affects car miles travelled can vary according to the local context, passenger characteristics, land-use features, and alternative modes of transportation [14]. Multiple people can share a ride in a vehicle with newer services. If this type of service becomes popular, car miles will be reduced [65].

Barriers to the growth in shared mobility also stem from long-held customs and beliefs, such as the desire to maintain independence, the importance put on maintaining private space, and the status conferred by private automobile ownership.

\section{Wanneroo Case study}

\subsection{Methods and Measures}

Based on factors identified from the existing literature and the input of various stakeholders, a questionnaire was developed. An invitation to complete the anonymous online questionnaire was provided to Wanneroo residents and those travelling around Wanneroo, 18 years of age or over. We received and analysed 220 completed questionnaires. This number of respondents was deemed satisfactory, given that 8500 people aged 18 and or live in Wanneroo. The demographic breakdown of participants roughly represents the male/female ratio, ages, number of children and household income of those living in Wanneroo [4].

The questionnaire was divided into three sections. The first part covered information on social demographic characteristics such as age, gender, number of children in the home, and annual income.

The second part categorised respondents as shared mobility users and non-shared mobility users based on their self-reported behaviour for various types of trips. The questions are designed to answer two questions: (1) the use of shared mobility in the past year, taking into account age and number of children at the address, and (2) the use of shared mobility in the next 12 months. The intention to use shared mobility options in the future was measured using a six-point Likert scale (1: Yes; 2: Very likely; 3: Unsure; 4: Unlikely; 5: No; 6: Unavailable to me)

The third section assessed participant attitudes towards four shared mobility optionsride sharing, car sharing, carpooling, and bike sharing - in relation to participant age and annual income before tax. All items were evaluated on a five-point Likert scale, ranging from 1 (clearly describes my feelings) to 5 (does not describe my feelings). The following Tables 2-5 summarise the demographic data obtained from participants: Table 2. Age of respondents; Table 3. Gender of respondents; Table 4. Number of children living at the address; Table 5. Annual household income of respondents. 
Table 2. Age of respondents.

\begin{tabular}{ccc}
\hline Age & Frequency & Percentage \\
\hline $18-24$ & 16 & 8 \\
$25-34$ & 44 & 20 \\
$35-44$ & 61 & 28 \\
$45-54$ & 44 & 20 \\
$55-64$ & 36 & 16 \\
$65-74$ & 16 & 7 \\
75 or over & 3 & 1 \\
\hline
\end{tabular}

Table 3. Gender of respondents.

\begin{tabular}{ccc}
\hline Gender & Frequency & Percentage \\
\hline Male & 86 & 39 \\
Female & 134 & 61 \\
Transgender & 0 & 0 \\
Not identify as female, male & 0 & 0 \\
or transgender & & \\
\hline
\end{tabular}

Table 4. Number of children living at the address.

\begin{tabular}{ccc}
\hline Number of Children Living at this Address & Frequency & Percentage \\
\hline 0 & 112 & 51 \\
1 & 39 & 18 \\
2 & 46 & 21 \\
3 & 17 & 8 \\
4 & 4 & 2 \\
More than 4 & 2 & 1 \\
\hline
\end{tabular}

Table 5. Annual household income of respondents.

\begin{tabular}{ccc}
\hline Annual Household Income & Frequency & Percentage \\
\hline Under $\$ 10,400$ & 11 & 5 \\
$\$ 10,400-\$ 20,799$ & 11 & 5 \\
$\$ 20,800-\$ 36,399$ & 24 & 11 \\
$\$ 36,400-\$ 51,999$ & 33 & 15 \\
$\$ 52,000-\$ 77,999$ & 31 & 14 \\
$\$ 78,000-\$ 103,999$ & 33 & 15 \\
$\$ 104,000-\$ 129,999$ & 20 & 9 \\
$\$ 130,000$ and over & 24 & 11 \\
Prefer not to answer & 33 & 15 \\
\hline
\end{tabular}

Our sample consisted of 220 Wanneroo residents and those travelling around Wanneroo, 18 years of age or over. We divided the respondents into seven age groups: (1) eight per cent were between the ages of 18 and 24, (2) twenty per cent were between the ages of 25 and 34, (3) twenty-eight per cent were between the ages of 35 and 44, (4) twenty per cent were between the ages of 45 and 54, (5) sixteen per cent were between the ages of 55 and $64,(6)$ seven per cent were between the ages of 65 and 74, and (7) one per cent were 75 or older. Number of children, participant gender, and income level were also considered. More women than men answered the questionnaire (sixty-one per cent compared to thirty-nine per cent), and approximately fifty-one per cent of respondents have zero children. Thirty-nine per cent of the participants have one or two children. Income level for thirty-six per cent of respondents was less than AUD 52,000, while only thirteen per cent had an income level of AUD 130,000 and over. 


\subsection{Results and Discussion}

The following section presents a selection of results from the survey on respondent attitude and use of shared mobility. See Table 6.

Table 6. Use of shared mobility in the past year (excludes taxi services).

\begin{tabular}{ccccccccc}
\hline \multirow{2}{*}{ Age } & \multicolumn{7}{c}{ Use in the Past Year } \\
\cline { 2 - 9 } & \multicolumn{2}{c}{ Ride Sharing Service } & \multicolumn{2}{c}{ Car Sharing Services } & \multicolumn{2}{c}{ Carpooling } & \multicolumn{2}{c}{ Bike Sharing Scheme } \\
\cline { 2 - 9 } & Yes & No & Yes & No & Yes & No & Yes & No \\
\hline $18-24$ & $66.67 \%$ & $33.33 \%$ & $22.22 \%$ & $77.78 \%$ & $33.33 \%$ & $66.67 \%$ & $0.00 \%$ & $100.00 \%$ \\
$25-34$ & $58.33 \%$ & $41.67 \%$ & $4.17 \%$ & $95.83 \%$ & $29.17 \%$ & $70.83 \%$ & $12.50 \%$ & $87.50 \%$ \\
$35-44$ & $42.86 \%$ & $57.14 \%$ & $17.14 \%$ & $82.86 \%$ & $26.47 \%$ & $73.53 \%$ & $0.00 \%$ & $100.00 \%$ \\
$45-54$ & $45.83 \%$ & $54.17 \%$ & $8.33 \%$ & $91.67 \%$ & $8.33 \%$ & $91.67 \%$ & $4.17 \%$ & $95.83 \%$ \\
$55-64$ & $19.05 \%$ & $80.95 \%$ & $9.52 \%$ & $90.48 \%$ & $31.82 \%$ & $68.18 \%$ & $0.00 \%$ & $100.00 \%$ \\
$65-74$ & $11.11 \%$ & $88.89 \%$ & $0.00 \%$ & $100.00 \%$ & $11.11 \%$ & $88.89 \%$ & $0.00 \%$ & $100.00 \%$ \\
$>75$ & $0.00 \%$ & $100.00 \%$ & $0.00 \%$ & $100.00 \%$ & $0.00 \%$ & $100.00 \%$ & $0.00 \%$ & $100.00 \%$ \\
Total & $41.80 \%$ & $58.20 \%$ & $10.66 \%$ & $89.34 \%$ & $23.77 \%$ & $76.23 \%$ & $3.31 \%$ & $96.69 \%$ \\
\hline
\end{tabular}

Nearly forty-two per cent of respondents used ride sharing in the past year. Although most users were in the 18-24 age group, all age groups below 55 were not far behind. Use was lower for those aged 55 or over but it still remained a significant option. Car sharing was used less than ride sharing, but it still accounted for over ten per cent of respondents. Carpooling is a widely used mode of travel with almost one-quarter of respondents having carpooled in the past year. Bike sharing was less commonly used than the other forms of shared mobility. See Table 7.

Table 7. Number of children and the use of shared mobility in the past year.

\begin{tabular}{|c|c|c|c|c|c|c|c|c|}
\hline & & \multicolumn{6}{|c|}{ Number of Children at This Address } & \multirow[b]{2}{*}{ Total } \\
\hline & & 0 & 1 & 2 & 3 & 4 & $>4$ & \\
\hline \multirow{2}{*}{$\begin{array}{l}\text { In the last } 12 \text { months, I have used the following } \\
\text { sharing transport option-ride sharing service }\end{array}$} & Yes & $44 \%$ & $44 \%$ & $28 \%$ & $36 \%$ & $0 \%$ & $0 \%$ & $40 \%$ \\
\hline & No & $56 \%$ & $56 \%$ & $72 \%$ & $64 \%$ & $100 \%$ & $100 \%$ & $60 \%$ \\
\hline \multirow{2}{*}{$\begin{array}{l}\text { In the last } 12 \text { months, I have used the following } \\
\text { sharing transport option-car sharing services }\end{array}$} & Yes & $8 \%$ & $12 \%$ & $12 \%$ & $25 \%$ & $50 \%$ & $50 \%$ & $12 \%$ \\
\hline & No & $92 \%$ & $88 \%$ & $88 \%$ & $75 \%$ & $50 \%$ & $50 \%$ & $88 \%$ \\
\hline \multirow{2}{*}{$\begin{array}{l}\text { In the last } 12 \text { months, I have used the following } \\
\text { sharing transport option-carpooling arrangement }\end{array}$} & Yes & $25 \%$ & $17 \%$ & $16 \%$ & $18 \%$ & $100 \%$ & $100 \%$ & $22 \%$ \\
\hline & No & $75 \%$ & $83 \%$ & $84 \%$ & $82 \%$ & $0 \%$ & $0 \%$ & $78 \%$ \\
\hline \multirow{2}{*}{$\begin{array}{l}\text { In the last } 12 \text { months, I have used the following } \\
\text { sharing transport option-bike sharing scheme }\end{array}$} & Yes & $4 \%$ & $4 \%$ & $4 \%$ & $0 \%$ & $0 \%$ & $50 \%$ & $4 \%$ \\
\hline & No & $96 \%$ & $96 \%$ & $96 \%$ & $100 \%$ & $100 \%$ & $50 \%$ & $96 \%$ \\
\hline
\end{tabular}

Household size in terms of number of children did not make an impact on the use of shared mobility and families of all sizes used shared mobility options for travel. Text comments from respondents indicated that they would use shared mobility more if safety devices such as child restraints and baby seats were fitted in vehicles. See Table 8 .

The pattern of use of shared mobility in the next 12 months was quite similar to that of shared mobility options used in the past year. The majority of the respondents in the age groups 18-24 and 55 or over reported that shared mobility options were not available to them. The highest group of intention users was the 25-54 age group, followed by the 18-24 age group. Use decreased sharply for the 55 or over group. Ride sharing was selected the most, followed by carpooling. Car sharing was considered more by the 55-64 age group. Bike sharing continued to be less commonly considered than the other forms of shared mobility. See Table 9. 
Table 8. Age and the use of shared mobility in the next 12 months.

\begin{tabular}{|c|c|c|c|c|c|c|c|c|c|}
\hline & & \multicolumn{7}{|c|}{ Age } & \multirow{2}{*}{ Total } \\
\hline & & $18-24$ & $25-34$ & $35-44$ & $45-54$ & $55-64$ & $65-74$ & $>75$ & \\
\hline \multirow{6}{*}{$\begin{array}{l}\text { I will use ride sharing more } \\
\text { often in the next } 12 \text { months }\end{array}$} & Yes & $0 \%$ & $9 \%$ & $6 \%$ & $18 \%$ & $0 \%$ & $0 \%$ & $0 \%$ & $7 \%$ \\
\hline & Very likely & $14 \%$ & $18 \%$ & $22 \%$ & $27 \%$ & $11 \%$ & $0 \%$ & $0 \%$ & $19 \%$ \\
\hline & Unsure & $14 \%$ & $18 \%$ & $17 \%$ & $18 \%$ & $67 \%$ & $33 \%$ & $0 \%$ & $25 \%$ \\
\hline & Unlikely & $0 \%$ & $36 \%$ & $39 \%$ & $9 \%$ & $0 \%$ & $0 \%$ & $0 \%$ & $20 \%$ \\
\hline & No & $14 \%$ & $9 \%$ & $11 \%$ & $18 \%$ & $0 \%$ & $33 \%$ & $0 \%$ & $12 \%$ \\
\hline & Unavailable to me & $58 \%$ & $10 \%$ & $5 \%$ & $10 \%$ & $22 \%$ & $34 \%$ & $100 \%$ & $17 \%$ \\
\hline \multirow{6}{*}{$\begin{array}{l}\text { I will use car sharing more } \\
\text { often in the next } 12 \text { months }\end{array}$} & Yes & $14 \%$ & $0 \%$ & $6 \%$ & $0 \%$ & $11 \%$ & $0 \%$ & $0 \%$ & $5 \%$ \\
\hline & Very likely & $0 \%$ & $9 \%$ & $17 \%$ & $9 \%$ & $11 \%$ & $0 \%$ & $0 \%$ & $10 \%$ \\
\hline & Unsure & $14 \%$ & $18 \%$ & $17 \%$ & $27 \%$ & $56 \%$ & $33 \%$ & $0 \%$ & $25 \%$ \\
\hline & Unlikely & $0 \%$ & $45 \%$ & $33 \%$ & $27 \%$ & $0 \%$ & $0 \%$ & $0 \%$ & $24 \%$ \\
\hline & No & $29 \%$ & $18 \%$ & $11 \%$ & $27 \%$ & $0 \%$ & $33 \%$ & $0 \%$ & $17 \%$ \\
\hline & Unavailable to me & $43 \%$ & $10 \%$ & $16 \%$ & $10 \%$ & $22 \%$ & $34 \%$ & $100 \%$ & $19 \%$ \\
\hline \multirow{6}{*}{$\begin{array}{l}\text { I will use carpooling more } \\
\text { often in the next } 12 \text { months }\end{array}$} & Yes & $14 \%$ & $0 \%$ & $6 \%$ & $0 \%$ & $0 \%$ & $33 \%$ & $0 \%$ & $5 \%$ \\
\hline & Very likely & $14 \%$ & $18 \%$ & $22 \%$ & $27 \%$ & $11 \%$ & $0 \%$ & $0 \%$ & $19 \%$ \\
\hline & Unsure & $14 \%$ & $9 \%$ & $22 \%$ & $9 \%$ & $44 \%$ & $33 \%$ & $0 \%$ & $20 \%$ \\
\hline & Unlikely & $0 \%$ & $36 \%$ & $33 \%$ & $36 \%$ & $11 \%$ & $0 \%$ & $0 \%$ & $25 \%$ \\
\hline & No & $14 \%$ & $27 \%$ & $11 \%$ & $18 \%$ & $12 \%$ & $0 \%$ & $0 \%$ & $15 \%$ \\
\hline & Unavailable to me & $44 \%$ & $10 \%$ & $6 \%$ & $10 \%$ & $22 \%$ & $34 \%$ & $100 \%$ & $16 \%$ \\
\hline \multirow{6}{*}{$\begin{array}{l}\text { I will use bike sharing more } \\
\text { often in the next } 12 \text { months }\end{array}$} & Yes & $0 \%$ & $9 \%$ & $0 \%$ & $8 \%$ & $0 \%$ & $0 \%$ & $0 \%$ & $3 \%$ \\
\hline & Very likely & $0 \%$ & $0 \%$ & $6 \%$ & $8 \%$ & $11 \%$ & $0 \%$ & $0 \%$ & $5 \%$ \\
\hline & Unsure & $0 \%$ & $0 \%$ & $22 \%$ & $8 \%$ & $12 \%$ & $0 \%$ & $0 \%$ & $10 \%$ \\
\hline & Unlikely & $14 \%$ & $55 \%$ & $39 \%$ & $9 \%$ & $0 \%$ & $0 \%$ & $0 \%$ & $25 \%$ \\
\hline & No & $15 \%$ & $9 \%$ & $17 \%$ & $67 \%$ & $33 \%$ & $67 \%$ & $0 \%$ & $30 \%$ \\
\hline & Unavailable to me & $71 \%$ & $27 \%$ & $16 \%$ & $0 \%$ & $44 \%$ & $33 \%$ & $100 \%$ & $27 \%$ \\
\hline
\end{tabular}

Table 9. Age and attitude towards shared mobility.

\begin{tabular}{|c|c|c|c|c|c|c|c|c|c|}
\hline & & \multicolumn{7}{|c|}{ Age } & \multirow{2}{*}{ Total } \\
\hline & & $18-24$ & $25-34$ & $35-44$ & $45-54$ & $55-64$ & $65-74$ & $>75$ & \\
\hline \multirow{2}{*}{$\begin{array}{l}\text { I am positive about } \\
\text { ride sharing }\end{array}$} & Describes my feelings & $62 \%$ & $81 \%$ & $61 \%$ & $63 \%$ & $56 \%$ & $38 \%$ & $0 \%$ & $63 \%$ \\
\hline & $\begin{array}{l}\text { Does not describe } \\
\text { my feelings }\end{array}$ & $38 \%$ & $19 \%$ & $39 \%$ & $37 \%$ & $44 \%$ & $63 \%$ & $100 \%$ & $37 \%$ \\
\hline \multirow{2}{*}{$\begin{array}{c}\text { I am positive about } \\
\text { car sharing }\end{array}$} & Describes my feelings & $43 \%$ & $57 \%$ & $48 \%$ & $50 \%$ & $61 \%$ & $14 \%$ & $0 \%$ & $50 \%$ \\
\hline & $\begin{array}{l}\text { Does not describe } \\
\text { my feelings }\end{array}$ & $57 \%$ & $43 \%$ & $52 \%$ & $50 \%$ & $39 \%$ & $86 \%$ & $100 \%$ & $50 \%$ \\
\hline \multirow{2}{*}{$\begin{array}{l}\text { I am positive about } \\
\text { carpooling }\end{array}$} & Describes my feelings & $62 \%$ & $62 \%$ & $45 \%$ & $50 \%$ & $72 \%$ & $50 \%$ & $0 \%$ & $56 \%$ \\
\hline & $\begin{array}{l}\text { Does not describe } \\
\text { my feelings }\end{array}$ & $38 \%$ & $38 \%$ & $55 \%$ & $50 \%$ & $28 \%$ & $50 \%$ & $100 \%$ & $44 \%$ \\
\hline \multirow{2}{*}{$\begin{array}{l}\text { I am positive about } \\
\text { bike sharing }\end{array}$} & Describes my feelings & $13 \%$ & $43 \%$ & $40 \%$ & $35 \%$ & $47 \%$ & $29 \%$ & $0 \%$ & $38 \%$ \\
\hline & $\begin{array}{c}\text { Does not describe } \\
\text { my feelings }\end{array}$ & $87 \%$ & $57 \%$ & $60 \%$ & $65 \%$ & $53 \%$ & $71 \%$ & $100 \%$ & $62 \%$ \\
\hline
\end{tabular}

Respondents generally have positive feelings towards ride sharing, with sixty-three per cent positive and thirty-seven per cent not positive. The results were evenly divided for car sharing $(50 \%-50 \%)$, and more were positive towards carpooling (56\%) than not positive (44\%). Thirty-eight per cent of respondents felt positively about bike sharing as opposed to sixty-two per cent who did not. This is in contrast to the low percentage of people who have actually used bike sharing in the past year. Positive attitude towards shared mobility reduced as the age of respondents increased. See Table 10. 
Table 10. Income and attitude towards shared mobility.

\begin{tabular}{|c|c|c|c|c|c|c|c|c|c|c|c|}
\hline & & \multicolumn{9}{|c|}{ Annual Income before Tax } & \multirow[t]{2}{*}{ Total } \\
\hline & & $\begin{array}{c}\$ 1- \\
\$ 10,399\end{array}$ & $\begin{array}{l}\$ 10,400- \\
\$ 20,799\end{array}$ & $\begin{array}{l}\$ 20,800- \\
\$ 36,399\end{array}$ & $\begin{array}{l}\$ 36,400- \\
\$ 51,999\end{array}$ & $\begin{array}{l}\$ 52,000- \\
\$ 77,999\end{array}$ & $\begin{array}{l}\$ 78,000- \\
\$ 103,999\end{array}$ & $\begin{array}{l}\$ 104,000- \\
\$ 129,999\end{array}$ & $\begin{array}{l}\$ 130,000 \\
\text { or Over }\end{array}$ & $\begin{array}{l}\text { Prefer not to } \\
\text { Answer }\end{array}$ & \\
\hline \multirow{2}{*}{$\begin{array}{l}\text { "I am positive } \\
\text { about } \\
\text { ride sharing" }\end{array}$} & $\begin{array}{c}\text { Describes my } \\
\text { feelings }\end{array}$ & $57 \%$ & $75 \%$ & $62.5 \%$ & $50 \%$ & $75 \%$ & $75 \%$ & $77 \%$ & $69 \%$ & $47 \%$ & $65 \%$ \\
\hline & $\begin{array}{l}\text { Does not describe } \\
\text { my feelings }\end{array}$ & $43 \%$ & $25 \%$ & $37.5 \%$ & $50 \%$ & $25 \%$ & $25 \%$ & $23 \%$ & $31 \%$ & $53 \%$ & $35 \%$ \\
\hline \multirow{2}{*}{$\begin{array}{c}\text { "I am positive } \\
\text { about } \\
\text { car sharing" }\end{array}$} & $\begin{array}{l}\text { Describes my } \\
\text { feelings }\end{array}$ & $43 \%$ & $33 \%$ & $56 \%$ & $64 \%$ & $55 \%$ & $60 \%$ & $62 \%$ & $50 \%$ & $25 \%$ & $52 \%$ \\
\hline & $\begin{array}{l}\text { Does not describe } \\
\text { my feelings }\end{array}$ & $57 \%$ & $67 \%$ & $44 \%$ & $36 \%$ & $45 \%$ & $40 \%$ & $38 \%$ & $50 \%$ & $75 \%$ & $48 \%$ \\
\hline \multirow{2}{*}{$\begin{array}{l}\text { “I am positive } \\
\text { about } \\
\text { carpooling" }\end{array}$} & $\begin{array}{l}\text { Describes my } \\
\text { feelings }\end{array}$ & $57 \%$ & $33 \%$ & $60 \%$ & $64 \%$ & $67 \%$ & $62.5 \%$ & $69 \%$ & $33 \%$ & $37.5 \%$ & $56 \%$ \\
\hline & $\begin{array}{l}\text { Does not describe } \\
\text { my feelings }\end{array}$ & $43 \%$ & $67 \%$ & $40 \%$ & $36 \%$ & $33 \%$ & $37.5 \%$ & $31 \%$ & $67 \%$ & $62.5 \%$ & $44 \%$ \\
\hline \multirow{2}{*}{$\begin{array}{c}\text { "I am positive } \\
\text { about } \\
\text { bike sharing" }\end{array}$} & $\begin{array}{l}\text { Describes my } \\
\text { feelings }\end{array}$ & $29 \%$ & $33 \%$ & $40 \%$ & $43 \%$ & $48 \%$ & $60 \%$ & $23 \%$ & $36 \%$ & $33 \%$ & $43 \%$ \\
\hline & $\begin{array}{l}\text { Does not describe } \\
\text { my feelings }\end{array}$ & $71 \%$ & $67 \%$ & $60 \%$ & $57 \%$ & $52 \%$ & $40 . \%$ & $77 \%$ & $64 \%$ & $67 \%$ & $57 \%$ \\
\hline
\end{tabular}

The literature assumes that cost savings are a key driver in the use of shared mobility. However, no discernible pattern can be detected in relation to income and attitude towards shared mobility from these data. Therefore, as the results indicate that preference for shared mobility is not related to income level, cost savings may not be a key driver, or all income levels may be equally concerned about cost savings.

Most of the users of shared mobility in the past year and the next 12 months were in the younger age groups (under 54). This result is in line with the literature [41,66], reporting that the highest car sharing members had a low mean age. Older respondents were less positive about shared mobility options than the younger age groups, consistent with the results reported for use of shared mobility, indicating that attitudes were the key driver in shaping choices [67]. Bike sharing challenges include strict cycling regulations, such as the fact that wearing a helmet is compulsory in Australia, which may make the schemes impractical for some respondents. Further, there is concern about safety when cycling on heavily car-dominated roads that lack adequate bicycle infrastructure [68]. Although income was found to have a strong relationship with use of shared mobility in many existing literature reviews $[4,68,69]$, our study did not find a link between cost savings and shared mobility services. An in-depth regression analysis needs to be conducted to clarify the impact of income factors on the use of shared mobility.

\section{Conclusions and Recommendation}

Our study investigated approximately 700 papers obtained from the Scopus database to determine contemporary research clusters on shared mobility. The findings from bibliometric analysis were then applied for the case study of Wanneroo, Australia. A specially designed questionnaire was sent to Wanneroo residents and those travelling around Wanneroo, 18 years of age or over, in order to investigate use of shared mobility and residents' future behaviour intentions.

Our findings suggest several vital insights. First, most respondents who had used shared mobility options in the past year were in the younger age groups (55 or lower). Second, participants in the younger age groups seemed to be more optimistic about shared mobility and were likely to use the service in the next 12 months. Third, household size measured by number of children was not associated with use of shared mobility. Fourth, no discernible relationship between annual income and positive attitude towards shared mobility was found. Fifth, bike sharing was less commonly used than the other forms of shared mobility.

The survey findings draw several suggestions for Wanneroo City Council and transportation authorities in Western Australia to consider when developing transport planning documents. The sharing economy has impacted travel behaviour and will continue to 
evolve along with technological advancements. These innovations must be integrated into transportation planning, striking a balance between the demand for mode choice and service equality. Further, more policies need to be introduced to build up trust in shared mobility services among the older age group and encourage this population to use shared mobility programs. Last but not least, policy makers should concentrate on increasing public awareness of shared mobility options, especially bike sharing services and provide incentives for participation, such as implementing the restriction of road lanes for vehicles carrying fewer than two passengers during rush hours. Although few people used bike sharing, there seems to be interest in this form of shared mobility among a significant portion of residents, so more promotional support and further development of bike lanes/zones for rider safety need to be investigated.

Author Contributions: C.S., F.J., S.B., and S.S., conceptualization; F.J. and T.L., data curation; C.S., F.J., and T.L., formal analysis; C.S., F.J., S.B., and S.S., investigation; C.S., F.J., and T.L., methodology; F.J., C.S., S.B., and S.S., project administration; F.J., C.S., S.B., and S.S., resources; T.L., software; F.J., supervision; F.J., validation; C.S., F.J., and T.L., visualization; C.S., F.J., and T.L., roles/writingoriginal draft; F.J., C.S., and T.L., writing-review and editing. All authors have read and agreed to the published version of the manuscript.

Funding: This research received no external funding.

Institutional Review Board Statement: Not applicable.

Informed Consent Statement: Not applicable.

Data Availability Statement: Data are not available.

Conflicts of Interest: The authors declare no conflict of interest.

\section{References}

1. Meng, L.; Somenahalli, S.; Berry, S. Policy implementation of multi-modal (shared) mobility: Review of a supply-demand value proposition canvas. Transp. Rev. 2020, 40, 670-684. [CrossRef]

2. Shaheen, S.; Chan, N.; Bansal, A.; Cohen, A. Shared Mobility: A Sustainability and Technologies Workshop-Definitions, Industry Developments, and Early Understanding; Transportation Sustainability Research Center, University of California, Berkeley and California Department of Transportation: Richmond, CA, USA, 2015.

3. Jiao, J.; Bischak, C.; Hyden, S. The impact of shared mobility on trip generation behavior in the US: Findings from the 2017 National Household Travel Survey. Travel Behav. Soc. 2020, 19, 1-7. [CrossRef]

4. Jie, F.; Standing, C.; Biermann, S.; Standing, S.; Le, T. Factors affecting the adoption of shared mobility systems: Evidence from Australia. Res. Transp. Bus. Manag. 2021, 100651. [CrossRef]

5. Rauch, D.E.; Schleicher, D. Like Uber, but for Local Government Policy: The Future of Local Regulation of the "Shared Economy"; Marron Institute of Urban Management: New York, NY, USA, 2015.

6. McKenzie, G. Urban mobility in the sharing economy: A spatiotemporal comparison of shared mobility services. Comput. Environ. Urban Syst. 2020, 79, 101418. [CrossRef]

7. Mourad, A.; Puchinger, J.; Chu, C. A survey of models and algorithms for optimizing shared mobility. Transp. Res. Part B Methodol. 2019, 123, 323-346. [CrossRef]

8. Shokouhyar, S.; Shokoohyar, S.; Sobhani, A.; Gorizi, A.J. Shared mobility in post-COVID era: New challenges and opportunities. Sustain. Cities Soc. 2021, 67, 102714. [CrossRef]

9. Hu, J.W.; Creutzig, F. A systematic review on shared mobility in China. Int. J. Sustain. Transp. 2021, 1-16. [CrossRef]

10. Anair, D.; Martin, J.; Moura, M.C.P.D.; Goldman, J. Ride-Hailing's Climate Risks: Steering a Growing Industry toward a Clean Transportation Future. Union of Concerned Scientists. 2020. Available online: https://www.ucsusa.org/resources/ride-hailingclimate-risks (accessed on 10 July 2021).

11. Suatmadi, A.Y.; Creutzig, F.; Otto, I.M. On-demand motorcycle taxis improve mobility, not sustainability. Case Stud. Transp. Policy 2019, 7, 218-229. [CrossRef]

12. Berger, C.; Chen, C.; Frey, B. Drivers of disruption? Estimating the Uber effect. Eur. Econ. Rev. 2018, 110, 197-210. [CrossRef]

13. Wallsten, S. The competitive effects of the sharing economy: How is Uber changing taxis? Technol. Policy Inst. 2015, 22, 1-21.

14. Goebel, B. Are Uber and Lyft Really 'Disrupting' Transportation? KQED News. 2015. Available online: https://www.kqed.org/ news /10766036/are-uber-and-lyft-really-disrupting-transportation (accessed on 20 January 2019).

15. Burghard, U.; Dütschke, E. Who wants shared mobility? Lessons from early adopters and mainstream drivers on electric carsharing in Germany. Transp. Res. Part D Transp. Environ. 2019, 71, 96-109. [CrossRef] 
16. Brimont, L.; Demailly, D.; Saujot, M.; Sartor, O. The New Collaborative Mobility Actors: From Promises to Challenges for Public Authorities. IDDRI. 2016. Available online: https://www.iddri.org/en/publications-and-events/study/new-collaborativemobility-actors-promises-challenges-public (accessed on 20 January 2019).

17. Neoh, J.G.; Chipulu, M.; Marshall, A. What encourages people to carpool? An evaluation of factors with meta-analysis. Transportation 2017, 44, 423-447. [CrossRef]

18. Loa, P.; Habib, K.N. Examining the influence of attitudinal factors on the use of ride-hailing services in Toronto. Transp. Res. Part A Policy Pract. 2021, 146, 13-28. [CrossRef]

19. McGrath, F. The Demographics of Uber's US Users. 16 August 2015. Available online: https://blog.globalwebindex.com/chartof-the-day/uber-demographics / (accessed on 15 January 2019).

20. Atkinson-Palombo, C.; Varone, L.; Garrick, N.W. Understanding the Surprising and Oversized Use of Ridesourcing Services in Poor Neighborhoods in New York City. Transp. Res. Rec. 2019, 2673, 185-194. [CrossRef]

21. Brown, A.E. Who and where rideshares? Rideshare travel and use in Los Angeles. Transp. Res. Part A 2020, 136, 120-134. [CrossRef]

22. Gehrke, S.R.; Felix, A.; Reardon, T.G. Fare Choices: A Survey of Ride-hailing Passengers in Metro Boston. 2018. Available online: http:/ / www.mapc.org/wp-content/uploads/2018/02/Fare-Choices-MAPC.pdf (accessed on 20 July 2020).

23. Anaya-Boig, E.; Douch, J.; Castro, A. The death and life of bike-sharing schemes in Spain: 2003-2018. Transp. Res. Part A Policy Pract. 2021, 149, 227-236. [CrossRef]

24. Radzimski, A.; Dziecielski, M. Exploring the relationship between bike-sharing and public transport in Poznań, Poland. Transp. Res. Part A Policy Pract. 2021, 145, 189-202. [CrossRef]

25. Nagariya, R.; Kumar, D.; Kumar, I. Service supply chain: From bibliometric analysis to content analysis, current research trends and future research directions. Benchmarking Int. J. 2020, 28, 333-369. [CrossRef]

26. Clauset, A.; Newman, M.E.J.; Moore, C. Finding community structure in very large networks. Phys. Rev. 2004, 70, 1-6. [CrossRef]

27. Radicchi, F.; Castellano, C.; Cecconi, F.; Loreto, V.; Parisi, D. Defining and identifying communities in networks. Proc. Natl. Acad. Sci. USA 2004, 101, 2658-2663. [CrossRef] [PubMed]

28. Blondel, V.D.; Guillaume, J.L.; Lambiotte, R.; Lefebvre, E. Fast unfolding of communities in large networks. J. Stat. Mech. Theor. Exp. 2008, 2008, P10008. [CrossRef]

29. Xu, X.; Chen, X.; Jia, F.; Brown, S.; Gong, Y.; Xu, Y. Supply chain finance: A systematic literature review and bibliometric analysis. Int. J. Prod. Econ. 2018, 204, 160-173. [CrossRef]

30. Business Travel. A New Report Explores the Benefits of Uber. 2016. Available online: http://www.news.com.au/finance/ business/travel/a-new-report-explores-the-benefits-of-uber/newsstory/5e41687c9bc2614f07015f85eb784f7f (accessed on 20 January 2019).

31. Deloitte. Review of the Collaborative Economy in NSW. 2015. Available online: https://www.finance.nsw.gov.au/sites/default/ files/Deloitte_Report_Review_Collaborative_Economy.pdf (accessed on 20 January 2019).

32. Deloitte. Economic Effects of Ridesharing in Australia. Uber. 2016. Available online: https://www2.deloitte.com/au/en/pages/ economics/articles/economic-effects-ridesharing-australia-uber.html (accessed on 20 January 2019).

33. Eggers, W.D.; Macmillan, P. Why governments should get behind ride-sharing. Harv. Bus. Rev. 2013, 13. Available online: https:/ /hbr.org/2013/11/why-governments-should-get-behind-ride-sharing (accessed on 20 January 2019).

34. Belk, R. You are what you can access: Sharing and collaborative consumption online. J. Bus. Res. 2014, 67, 1595-1600. [CrossRef]

35. Caulfield, B. Estimating the environmental benefits of ride-sharing: A case study of Dublin. Transp. Res. Part D Transp. Environ. 2009, 14, 527-531. [CrossRef]

36. Delhomme, P.; Gheorghiu, A. Comparing French carpoolers and non-carpoolers: Which factors contribute the most to carpooling? Transp. Res. Part D Transp. Environ. 2016, 42, 1-15. [CrossRef]

37. Viti, F.; Croman, F. Equilibrium and sensitivity analysis of dynamic rider sharing. In Proceedings of the 16th International IEEE Annual Conference on Intelligent Transportation System, The Hague, The Netherlands, 6-9 October 2013.

38. Deakin, E.; Karen, T.F.; Kevin, M.S. Markets for dynamic ride-sharing? Case study of Berkeley, California. Transp. Res. Rec. J. Transp. Res. Board 2011, 2178, 131-137.

39. Vanoutrive, T.; Van De Vijver, E.; Van Malderen, L.; Jourquin, B.; Thomas, I.; Verhetsel, A.; Witlox, F. What determines carpooling to workplaces in Belgium: Location, organisation, or promotion? J. Transp. Geogr. 2012, 22, 77-86. [CrossRef]

40. Coll, M.H.; Vandersmissen, M.H.; Theriault, M. Modelling spatio-temporal diffusion of car-sharing membership in Quebec City. J. Transp. Geogr. 2014, 38, 22-37. [CrossRef]

41. Efthymiou, D.; Antoniou, C.; Waddell, P. Factors affecting the adoption of vehicle sharing systems by young drivers. Transp. Policy 2013, 29, 64-73. [CrossRef]

42. Prieto, M.; Baltas, G.; Stan, V. Car sharing adoption intention in urban areas: What are the key sociodemographic drivers? Transp Res. Part A Policy Pract. 2017, 101, 218-227. [CrossRef]

43. Campbell, A.A.; Cherry, C.R.; Ryerson, M.S.; Yang, X. Factors influencing the choice of shared bicycles and shared electric bikes in Beijing. Transp. Res. Part C Emerg. Technol. 2016, 67, 399-414. [CrossRef]

44. Fishman, E.; Washington, S.; Haworth, N. Barriers and facilitators to public bicycle scheme use: A qualitative approach. Transp. Res. Part F Traffic Psychol. Behav. 2012, 15, 686-698. [CrossRef] 
45. Zhao, J.; Deng, W.; Song, Y. Ridership and effectiveness of bike sharing: The effects of urban features and system characteristics on daily use and turnover rate of public bikes in China. Transp. Policy 2014, 35, 253-264. [CrossRef]

46. Rixey, R. Station-Level Forecasting of bikesharing ridership: Station network effects in Three US systems. Transp. Res. Rec. J. Transp. Res. Board 2013, 2387, 46-55. [CrossRef]

47. Wang, X.; Lindsey, G.; Schoner, J.E.; Harrison, A. Modeling bike share station activity: Effects of nearby businesses and jobs on trips to and from Stations. J. Urban Plan. Dev. 2015, 142, 04015001. [CrossRef]

48. Faghih-Imani, A.; Eluru, N.; El-Geneidy, A.M.; Rabbat, M.; Haq, U. How land-use and urban form impact bicycle flows: Evidence from the bicycle-sharing system (BIXI) in Montreal. J. Transp. Geogr. 2014, 41, 306-314. [CrossRef]

49. Guo, Y.; Zhou, J.; Wu, Y.; Li, Z. Identifying the factors affecting bike-sharing usage and degree of satisfaction in Ningbo, China. PLoS ONE 2017, 12, e0185100. [CrossRef]

50. Standing, C.; Standing, S.; Biermann, S. The implications of the sharing economy for transport. Transp. Rev. 2019, 39, 226-242. [CrossRef]

51. Kaplan, A.M.; Haenlein, M. Users of the world, unite! The challenges and opportunities of Social Media. Bus. Horiz. 2010, 53, 59-68. [CrossRef]

52. Hamari, J.; Sjöklint, M.; Ukkonen, A. The sharing economy: Why people participate in collaborative consumption. J. Assoc. Inf. Science Technol. 2015, 67, 2047-2059. [CrossRef]

53. Wasko, M.M.; Faraj, S. Why should I share? Examining social capital and knowledge contribution in electronic networks of practice. MIS Q. 2005, 29, 35-57. [CrossRef]

54. Liang, T.P.; Turban, E. Introduction to the special issue social commerce: A research framework for social commerce. Int. J. Electron. Commer. 2011, 16, 5-14. [CrossRef]

55. Harding, S.; Kandlikar, M.; Gulati, S. Taxi apps, regulation, and the market for taxi journeys. Transp. Res. Part A Policy Pract. 2016, 88, 15-25. [CrossRef]

56. Parise, S.; Guinan, P.J.; Kafka, R. Solving the crisis of immediacy: How digital technology can transform the customer experience. Bus. Horiz. 2016, 59, 411-420. [CrossRef]

57. Bardhi, F.; Eckhardt, G.M. Access-Based Consumption: The Case of Car Sharing. J. Consum. Res. 2012, 39, 881-898. [CrossRef]

58. Rifkin, J. The Age of Access: The New Culture of Hypercapitalism Where All of Life Is a Paid for Experience; Penguin Putnam, Inc.: New York, NY, USA, 2000.

59. Chen, Y. Possession and Access: Consumer Desires and Value Perceptions Regarding Contemporary Art Collection and Exhibit Visits. J. Consum. Res. 2009, 35, 925-940. [CrossRef]

60. Karlsson, I.C.M.; Mukhtar-Landgren, D.; Smith, G.; Koglin, T.; Kronsell, A.; Lund, E.; Sarasini, S.; Sochor, J. Development and implementation of Mobility-as-a-Service-A qualitative study of barriers and enabling factors. Transp. Res. Part A Policy Pract. 2020, 131, 283-295. [CrossRef]

61. Washington, D. State Govt and Uber End Standoff. 2017. Available online: http://indaily.com.au/news/local/2017/03/31/stategovt-and-uber-end-stand-off/ (accessed on 20 January 2019).

62. Cannon, S.; Summers, L.H. How Uber and the sharing economy can win over regulators. Harv. Bus. Rev. 2014, 13, 24-28. Available online: https:/ / hbr.org/2014/10/how-uber-and-the-sharing-economy-can-win-over-regulators (accessed on 20 January 2019).

63. Ranchordás, S. Does sharing mean caring: Regulating innovation in the sharing economy. Minn. JL Sci. Tech. 2015, 16, 413.

64. Rayle, L.; Shaheen, S.; Chan, N.; Dai, D.; Cervero, R. App-Based, On-Demand Ride Services: Comparing Taxi and Ride sourcing Trips and User Characteristics in San Francisco University of California Transportation Center (UCTC); University of California: Berkeley, CA, USA, 2014.

65. Circella, G.; Tiedeman, S.H.; Alemi, F.; Mokhtarian, P. What Affects U.S. Passenger Travel? Current Trends and Future Perspectives. National Center for Sustainable Transportation. 2016. Available online: http:/ / www.dot.ca.gov/research/researchreports/ reports/2016/CA16-2825_FinalReport.pdf (accessed on 20 January 2019).

66. Becker, H.; Ciari, F.; Axhausen, K.W. Comparing car-sharing schemes in Switzerland: User groups and usage patterns. Transp. Res. Part A Policy Pract. 2017, 97, 17-29. [CrossRef]

67. Rahimi, A.; Azimi, G.; Jin, X. Examining human attitudes toward shared mobility options and autonomous vehicles. Transp. Res. Part F Traffic Psychol. Behav. 2020, 72, 133-154. [CrossRef]

68. Nikitas, A. Understanding bike-sharing acceptability and expected usage patterns in the context of a small city novel to the concept: A story of 'Greek Drama'. Transp. Res. Part F Traffic Psychol. Behav. 2018, 56, 306-321. [CrossRef]

69. Dias, F.F.; Lavieri, P.S.; Garikapati, V.M.; Astroza, S.; Pendyala, R.M.; Bhat, C.R. A behavioral choice model of the use of car-sharing and ride-sourcing services. Transportation 2017, 44, 1307-1323. [CrossRef] 